\title{
Novel Mechanisms of Immune Evasion by Schistosoma mansoni
}

\author{
Zvi Fishelson
}

Department of Cell Biology and Histology, Sackler School of Medicine, Tel Aviv University, Tel Aviv 69978, Israel

The interaction of Schistosoma mansoni with its host's immune system is largely affected by multiple specific and non-specific evasion mechanisms employed by the parasite to reduce the host's immune reactivity. Only little is known about these mechanisms on the molecular level. The four molecules described below are intrinsic parasitic proteins recently identified and studied in our laboratory.

1. $\mathrm{m} 28$ - A $28 \mathrm{kDa}$ membrane serine protease. $m 28$ cleaves $i C 3 b$ and can thus restrict attack by effector cells utilizing complement receptors (especially CR3). Treatment with protease inhibitors potentiates killing of schistosomula by complement plus neutrophils.

2. Smpi56 - A 56kDa serine protease inhibitor. Smpi56 binds covalently to $m 28$ and to neutrophil's elastase and blocks their proteolytic activity.

3. $\mathrm{P} 70$ - A 70kDa C3b binding protein. The postulated activity of $P 70$ includes binding to $C 3 b$ and blocking of complement activation at the C3 step.

4. SCIP-1 - A 94kDa schistosome complement inhibitor. SCIP-1 shows antigenic and functional similarities to the human $18 \mathrm{kD}$ a complement inhibitor CD59. Like CD59, SCIP-I binds to C8 and C9 and blocks formation of the complement membrane attack complex. Antibodies directed to human CD59 bind to schistosomula and potentiate their killing by complement.

The structure and function of these four proteins as well as their capacity to induce protection from infection with $\mathrm{S}$. mansoni are under investigation.

Key words: immune evasion - complement - protease - inhibitor - CD59

Cercariae of Schistosoma mansoni are well adapted to survive for several höurs in fresh water while searching for a compatible host. However, their heavy "armor" (the glycocalyx) and strong "engine" (the tail) will hamper their survival inside the host (McLaren 1980). Therefore, the penetrating larvae have to get rid of their glycocalyx and tail as soon as they are within the host. The larvae that migrate from the skin to the lungs and then to the liver and mesenteric veins, keep developing, transforming and adapting to their new habitat. Eventually, the mature worms reside within the mesenteric veins for years, in continuous contact with the host's blood. The developing and mature worms must face multiple challenges imposed on them by the host's defense mechanisms. Innate and induced immunity, mediated by complement, antibodies and effector cells (neutrophils, macrophages monocytes, eosinophils and lymphocytes) combine in an effort of the host to reject the intruders. However, to escape from those

This research was supported by the MacArthur Foundation and the UNDP/ World Bank/WHO special programme for Research and Training in Tropical Diseases. hosts' effector mechanisms, the larvae and worms have developed multiple mechanisms of immune cvasion. Several review articles (Pearce \& Sher 1987, Damian 1989, Fishelson 1989, 1991a, Capron 1992) have summarized the state of the art in this rapidly developing field of research. Recently, our research has led us to identify four new proteins of $S$. mansoni which may contribute to its immunoresistance. Only these four proteins will be described here.

\section{PROTEOLYSIS OF COMPLEMENT PROTEINS} (M28)

Earlier studies (Gazzinelli \& Pellegrino 1964, Auriaut et al. 1981, 1982, Landsperger et al. 1982, Keene et al. 1983, Bogitsh \& Dresden 1983, Chappell \& Dresden 1987, McKerrow \& Doenhoff 1988 ) indicated that cercariae, schistosomula and adult worms produce several proteases expressing a wide range of substrate specificities. Some of the functions of these proteases are: assistance in penetration through the skin by the cercaria (McKerrow et al. 1991), degradation of the cercarial glycocalyx (Marikovsky et al. 1988a), cleavage of host's immunoglobulin (Auriaut et al. 1981) and food (hemoglobin) digestion (Chappell \& Dresden 1987).

Cercariae of $S$. mansoni produce and store in their acetabular cells a $28-\mathrm{kDa}$ serine protease 
(Fishelson et al. 1992). Upon skin invasion, the cercariae relcase this protease and utilize it to digest epidermal and dermal connective tissue proteins and to facilitate penetration (Cohen et al. 1991, McKerrow et al. 1991. Fishelson et al. 1992). The released 28-kDa protcase, present in a soluble form in cercarial secretions, was purified and characterized (Marikovsky et al. 1988b). Anti-protease antibodies raised in rabbits (Marikovsky et al. $1988 \mathrm{~b}$ ) were used to localize the 28-kDa protease in the acetabular cells of cercariac and on the surface of schistosomula (Marikovsky at al. 1990a). Binding of these antibodies to the surface of lungstage and adult worms was also detected by immunofluorescence (Ghendler, Parizade. Arnon and Fishelson, manuscript in preparation).

The possibility that the $28-\mathrm{kDa}$ ecto-protease ( $m 28$ ) contributes to the immunc evasion of $S$. mansoni was examincd. Incubation of schistosomula with human serum leads to activation of the complement system and binding of scveral complement proteins to the surface of the larvac. We have demonstrated binding of $\mathrm{C} 3$ (Marikovsky et al. 1990b) and C9 (Parizade et al. 1994) to the schistosomula: bound $\mathrm{C} 3 \mathrm{~b}$ and $\mathrm{iC} 3 \mathrm{~b}$ as well as polymerized $\mathrm{C} 9$ were identified. Bound $\mathrm{C} 3 \mathrm{~b}$ is known to facilitate formation of the membranc attack complex (MAC) of complement and thus polymerization of C9 and target cell lysis (Muller-Eberhard 1988). On the other hand, iC3b serves as an acceptor for the leukocyte complement receptor type 3 (CR3; CDI1b,CD 18), thus promoting leukocyte adhesion to iC3b-bearing cells and leukocyte-mediated lytic or inflammatory events (Lambris 1989 , Fishelson 1991b). Neutrophils, eosinophils and macrophages kill complement-opsonized schistosomula much better than non-opsonized schistosomula (Anwar et al. 1979, Ramalho-Pinto et al. 1979).

Purified human $\mathrm{C} 3, \mathrm{C} 3 \mathrm{~b}, \mathrm{iC} 3 \mathrm{~b}$ and $\mathrm{C} 9 \mathrm{can}$ be cleaved by the $28-\mathrm{kDa}$ soluble (ccrcarial secretion) or membrane (schistosomular) protease (Parizade et al. 1990. Ghendler et al. manuscript in preparation). Of these four substrate molecules, iC $3 b$ was found to be the most sensitive. We have, therefore, speculated that by cleaving iC $3 \mathrm{~b}$ molecules deposited on their surface, the schistosomula protect themselves from iC $3 b$-mediated lcukocyte-dependent killing. Indeed, treatment of schistosomula with the protcase inhibitor phenylmethanesulfonyl fluoride or soybcan trypsin inhibitor rendered schistosomula more sensitive to complement-mediated neutrophil-dependent killing (Ghendler et al. manuscript in preparation).

\section{INHIBITION OF NEUTROPHILS' ELASTASE (SMPI56)}

Proteases released from activated leukocytes can be harmful to pathogenic microorganisms. To avoid the action of these proteases, bacteria and parasites produce protease inhibitors (Suquet et al. 1984, Martzen et al. 1990, Shepherd et al. 1991, Bode \& Huber 1992). Recently, we have identified the presence of a serine protease inhibitor in tegumental detergent extracts from adult worms of $S$. mansoni (Ghendler et al. 1994). The protease inhibitor was found to be a 56-kDa protein capable of specifically binding to the $28-\mathrm{kDa}$ serine protease of S. mansoni and to pancreatic and ncutrophil elastases and inhibiting their activity. The protein was named Smpi56, for ' $S$. mansoni protcase inhibitor of $56-\mathrm{kDa}$ '. Our results indicated that Smi56 forms a covalent bond with the reactive scrine of the $28-\mathrm{kDa}$ protease and elastase. Smpi56 showed no reactivity with trypsin, chymotrypsin, proteinase $\mathrm{K}$ or urokinase.

By using biotinylated-elastase and streptavidinagarose, Smpi56 was isolated from crude worm extract in a single step (Ghendler et al. 1994). Rabbit antibodies prepared against Smpi56 could immunoprecipitate the $56-\mathrm{kDa}$ protease inhibitor and a 74-kDa complcx of protcase-protease inhibitor.

Part of the Smpi56 cDNA was isolated from a $S$. mansoni adult worm cDNA library. Analysis of its nucleotide sequence has identificd a concensus sequence of a reactive center present in members of the serpin family of scrine protease inhibitors (Ghendler et al. manuscript in preparation). The cDNA sequence of a postulated serpin of S. haematobium was deposited in GenEmbl by Blanton et al. (1994). Alignment of Smpi56's and S. haematobium serpin's cDNAs and their deduced protein sequences shows about $80 \%$ homology at the nucleotide level and $73 \%$ identify at the amino acid level between the two serpins.

\section{INHIBITION OF COMPLEMENT C3 DEPOSITION (P70)}

Trypsin-treated schistosomula are more sensitive to complement than control schistosomula (Marikovsky et al. 1990b). Trypsinization enhances deposition of $\mathrm{C} 3$ on treated schistosomula, suggesting that trypsin removes an inhibitor of $\mathrm{C} 3$ deposition. Known mammalian membrane protcins acting as inhibitors of $\mathrm{C} 3$ deposition, such as the complement receptor type 1 (CR1, CD35), decay accelerating factor (DAF, CD55) and membrane cofactor protein (MCP. CD46), bind to the $\mathrm{C} 3 \mathrm{~b}$ fragment of $\mathrm{C} 3$ or to the $\mathrm{C} 3$ convertases (Lambris 1989 , Fishelson 1991b). It has been previously suggested that schistosomula of $S$. mansoni express a receptor for C3b on their surface (Santoro 1982).

Immunoadsorption of a detergent extract or trypsin-released material from schistosomula and adult worms over a $\mathrm{C} 3 \mathrm{~b}-\mathrm{Sepharose}$ column permitted us to identify a $70-\mathrm{kDa} \mathrm{C} 3 \mathrm{~b}$ binding protein (Parizade, Arnon and Fishelson, manuscript 
in preparation). In addition. our results have clearly demonstrated in the trypsin-relcased material an activity inhibitory to $\mathrm{C} 3$ deposition on antibodycoated sheep erythrocytes. It is conceivable that the $70-\mathrm{kDa} \mathrm{C} 3 \mathrm{~b}$ binding protein is the regulatory protein limiting C3 deposition on schistosomula and adult worms of $S$. mansoni

\section{INHIBITION OF COMPLEMENT MAC FORMATION (SCIP-1)}

Complement resistant 24 hr-old schistosomula do not permit formation of the complement membrane attack complex (MAC) on their surface ( $\mathrm{Pa}$ rizade et al. 1994). The MAC is formed on trypsinized schistosomula. Detcrgent extracted proteins from schistosomula and adult worms inhibit lysis of sheep erythrocytes, even if added after C 5 b7 has been deposited on them (Parazide el al. 1994).

CD59 is an $18-20-\mathrm{kDa}$ membrane protein that has a broad tissue distribution in man (Davies et al. 1989, Meri et al. 1991). It is found on blood. epithelial and endothelial cells. linked to the cell membrane via a glycosyl phosphatidylinositol (GPI) anchor (Davies et al. 1989. Ratnoff et al. 1992). CD59 inhibits MAC assembly by binding to the complement components $\mathrm{C} 8$ and $\mathrm{C} 9$ (Meri et al. 1990. Rollins et al. 1991).

The MAC inhibitor present on schistosomula and adult worms of S. mansoni was identified as a CD59-like molecule by using polyclonai and monoclonal antibodies directed to human CD59 (Parizade et al. 1994). It is a 94-kDa protein synthesized by the parasite and attached to the surface of schistosomula probably via a GPI linker. This CD59-like protein was named 'schistosome complement inhibitory protein type-1' or SCIP-1 ( $\mathrm{Pa}-$ rizade et al. 1994).

Like CD59, SCIP-1 binds to human $\mathrm{C} 8$ and $\mathrm{C} 9$ and inhibits MAC formation. Blocking of the protective activity of SCIP-1 on intact schistosomula with polyclonal anti-CD59 antibodies permitted efficient killing of the schistosomula by human and guinea pig complement.

\section{CONCLUSIONS}

The surface of schistosomula and adult worms of S. mansoni is covered with numerous proteins, most of which play an essential role in the survival of the parasite within its host. Some of these proteins confer on the parasite protection from the host's immune system. Four intrinsic membrane proteins, which probably contribute to the immune evasiveness of $S$ mansoni, have been described above: (1) a $28-\mathrm{kDa}$ serine protease capable of cleaving the complement proteins $\mathrm{iC} 3 \mathrm{~b}, \mathrm{C} 3 \mathrm{~b}$ and $\mathrm{C} 9$ (Parizade et al. 1990); (2) a 56-kDa serine protease inhibitor (Smpi56) which can block activity of neutrophil's elastase (Ghendler et al. 1994): (3) a 70-kDa C.3b binding protein. probably inhibiting $\mathrm{C} 3$ deposition on the parasite (Parizade et al. 1990 ); and (4) a 94-kDa $\mathrm{C} 8 / \mathrm{C} 9$ binding protein (SCIP-1) which is related functionally and antigenically to human CD59 (Parizade el al. 1994). It is reasonable to assume that blocking the activity of these and other immune cvasion molecules in vivo will assist an infected host in combatting the parasite. Two additional schistosomal proteins recently described which may affect complement activation on the surface of the parasite are: 1. the 94-kDa paramyosin which binds to complement $\mathrm{Cl}$ (Laclette et al 1992), and 2. a 130-kDa C3 binding protein (Silva ot al. 1993). As suggested (Fishelson 1991a), one of these new immunoregulatory molecules may perhaps be an "Achilles" Heel" of S. mansoni. It is, therefore, important to cxamine whether any of them may be applied as vaccine to control schistosomiasis.

\section{REFERENCES}

Anwar ARE, Smithers $S$, Kay AB 1979. Killing of schistosomula of Schistosoma mansoni coated with antibody andor complement by human leukocytes in vitro; requirement for complement in preferential damage by cosinophils. J /mmmol 122:628-637.

Auriault C. Ouaissi MA, Torpier G, Eisen H, Capron $\Lambda$ 1981. Proteolytic cleavage of IgG bound to the Fo receptor of Schistosoma mansoni schistosomula. Parasite Immunol 3: 33-44.

Auriault C, Pierce R, Casari IM, Capron A 1982 . Neutral protease activities at different developmental stages of Schistosoma mansoni in mammalian host. Comp Biochem Phvsiol 72B: 377-384.

Blanton RI: Iicate LS. Aman RA 1994. Characterization of a native and recombinant Schistosoma haematobium serine protease inhibitor gene product. Molec Biochem Parasitol 63: 1-11.

Bode W, Huber R 1992 . Natural protein proteinase inhibitors and their interaction with proteinases. Lur J Biochem 204: 433-451

13ogitsh BJ. IJesden MH 198.3. Fluorescent histocinemistry of acid proteases in adult Schistosoma mansoni and Schistosoma japonicum. J Parasitol 69: 106110

Capron AR 1992. Immunity to schistosomes. Curr Top Immunol 4: 419.424

Chappell CL, Iresden MH 1987. Purification of cysteine proteinases from adult Schistosoma mansoni. Arch Biochem Biophys 256 : 560-568

Cohen Fi:, Gregoret LM, Amiri P. Aldape K, Railey J, and McKerrow JH 1991 . Arresting tissue invasion of a parasite by protease inhibitors chosen with the aid of computer modeling. Biochemistry $30: 11221-$ 11229

Damian RT 1989. Molecular mimicry: parasite evasion and host defense. Curr Top Microbiol Immunol /45: 101-125.

Davies A, Simmons DI, I lale G. Harrison RA, Tighe $\mathrm{H}$, Lachmann PJ Waldmann H 1989. CD59, an 
LY-6-like protein expressed in human lymphoid cells, regulates the action of the complement membrane attack complex on homologous cells. J Exp Med 170: 637-654.

Fishelson $Z$ 1989. Complement and parasitic trematodes. Parasitol Today 5: 19-25.

Fishelson Z 1991a. Complement cvasion by parasiles search for "Achilles" heel". Clin Exp Immtmol 86 Suppl: 47-52

Fishedson Z 199 Jb. Complement C3: A molecular mosaic of binding siles. Molec Immunol 28:545-552.

Fishelson 7. 1994. Complement-related proteins in pathogenic organisms. Springer Seminars in Immunophatol 15: 345-368.

Fishelson 7., Amiri P. Iriend DS. Marikovsky M. Petitt M, Newport G, McKerrow, JH 1992. Schistosoma mansoni: Cell-specific expression and secretion of a serine protease during development of eercariae. Exp Parasitol 75: 87-98.

Gazzinelli G, Pellegrino J 1964. Flastolytic activity of Schistosoma mansoni cercarial extract. I Parasitol 50: $591-592$

Ghendler Y, Arnon R, Fishelson 7. 1994. Schistosoma mansoni : Isolation and characterization of Smpi56, a novel serine prolease inhibitor. Lxp Parasitol 78 : $121-131$

Keene WE, Jeong KH, McKerrow JH, Werb Z 1983 Degradation of extracellular matrix by larvac of Schistosoma mansoni. II. Degradation by newly transformed and developing schistosomula. Lab $\mathrm{In}$ vest 49: 201-207.

Laclette JP, Shoemaker CB, Richter D, Areos I Panto N. Cohen C, Bing D, Nicholson WA 1992. Paramyosin inhibits complement $\mathrm{Cl} . J$ Immmol 148 : 124-128.

Lambris JD 1989. The third component of complement Curr Top Microbiol Immunol 153: 1-248.

Landsperger WJ, Stirewalt MA, Dresden MH 1982. Purification and properties of proteolytic enzyme from the cercariae of the human trematode parasite Schistosoma mansoni. Biochem J 201: 137-144.

Marikovsky M, Arnon R. I'ishelson Z 1988a. Proteases secreted by transforming schistosomula of Schistosoma mansoni promote resistance to killing by complcment. J Immumol I4l: 273-278.

Marikovsky M. Fishelson 7, Arnon R 1988b. Purification and partial characterization of proteases secreted by transforming schistosomula of Schistosoma mansoni. Mol Biochem Parasitol 30: 45-54

Marikovsky M, Arnon R. Fishelson Z 1990a. Schistosoma mansoni: Localization of the $28 \mathrm{kDa}$ secreted protease in cercaria. Parasit Immunol 12: 389-401.

Marikovsky M, Parizade M, Amon R, lishelson Z. 1990b. Complement regulation on the surface of cultured schistosomula and adult worms of $S_{\text {chistosoma }}$ mansoni. Eur J Immunol 20: 221-227.

Martzen MR, McMullen BA, Smith NE, Fujikawa K, Peanasky RJ 1990. Primary structure of the major pepsin inhibitor from the intestinal parasitic nematode Ascaris suum. Biochemistry 29: 7366-7372.
Mckerrow JH, Doenhoff MJ 1988. Schistosome protcases. Parasitol Todav 4: 334-340.

McKerrow JH, Newpor G, Fishelson Z 199]. Recent insights into the structure and function of a larval proteinase involved in host infection by a multicellular parasite. Proc Soc Exp Biol Med 197: 119-124.

McLaren DJ 1980. Schistosoma mansoni: the parasite surface in relation to host inmunity. Research Studies Press. I.etchworth. England . $+229 \mathrm{pp}$.

Meri S. Morgan BP. Davies A. Daniels RH, Olavesen MG, Waldmann H, Lachmann PJ 1990. Human protectin (CD59), an 18,000-20.000 MW compicment lysis restriction factor, inhibits $\mathrm{C} 5 \mathrm{~b}-8$ catalysed insertion of $\mathrm{C} 9$ into lipid bylayers. $\mathrm{Im}$. munology $7 /: 1-9$.

Meri S. Waldmann H, Lachmann PJ 1991. Distribution of protectin (CD59), a complement membrane attack inhibitor, in normal human tissues. Lab Invest 65: 532

Muller-Eberhard HJ 1988. Molecular organization and function of the complement system. Anmu Rev Biochem 57: 321-347.

Parizade M, Ghendler Y. Arnon R, Fishelson Z 1990. Resistance of the parasite Schistosoma mansoni to immune attack. HASEB J 4: A2228 (Abstr.).

Parizade M, Amon R, Lachmann PJ. Fishclson Z 1994 Functional and antigenic similarities between a $94 \mathrm{k}$ Da protein of schistosoma mansoni (SCIP-1) and human CD59. J Exp Med 179: 1625-1636.

Pearce I:J, Sher A 1987. Mechanisms of Immune evasion in schistosomiasis. Contr Microbiol Immmol 8: $219-232$

Ramalho-Pinto FJ, de Rossi R, Smithers SR 1979. Murine Schistosomiasis mansoni: anti-schistosomula antibody and the $\operatorname{IgC}$ sub clases involved in the complement- and eosinophil-mediated killing of schistosomula in vitro. Parasite Immunol 1: 2295.

Ratnoff WD, Kne $\mathrm{JJ}$, Prince GM. Okada I, Lachmann PJ, Medof ME 1992. Structural propertics of the glycoplasmanylinositol anchor phospholipid of the complement membrane attack complex inhibitor CD59. Clin Exp Immunol 87: 415-421

Rollins SA, Zhao J, Ninomiya H. Sims PJ 1991. Inhibition of homologous complement by CD59 is mediated by a species-selective recognition conferred through binding to $\mathrm{C} 8$ within $\mathrm{C} 5 \mathrm{~b}-8$ or $\mathrm{C} 9$ within C5b-9. J Immumol I 46: 2345-235l

Santoro $\mathrm{F}$ 1982. Interaction of complement with parasite surfaces. Clin Immunol Allergy 2: 639-654.

Shepherd JC, Aitken A. McManus IPP 1991. A protein secreted in vivo by Echinococcus granulosus inhibits elastase activity and neutrophil chemotaxis. $\mathrm{Mol}$ Biochem Parasitol 44: 81-90.

Silva EE, Clarke MW, Podesta RB 1993. Characterization of a C3 receptor on the envelope of Schistosoma mansoni. J Immunol 152: 7057-7066.

Suquet CM, Green-Edwards C. Leid RW 1984. Isolation and partial characterization of a proteinase inhibitor from the larval stage of the cestode, Taenia taeniaeformis. Int J Parasitol 14: 165-172. 